\title{
ReView article: The mountain motif in the Plot of MattheW
}

Author:

Gert J. Volschenk ${ }^{1}$

\author{
Affiliation: \\ ${ }^{1}$ Department of Systematic \\ Theology and Christian \\ Ethics, University of \\ Pretoria, South Africa
}

\section{Correspondence to:}

Gert Volschenk

email:

andries.vanaarde@up.ac.za

Postal address:

Faculty of Theology,

University of Pretoria,

Hatfield 0083, Pretoria,

South Africa

\section{Keywords:}

faith; Matthew; mountain motif; plot; Second Temple Judaism

\section{Dates:}

Received: 30 July 2009

Accepted: 22 Dec. 2009

Published: 03 Sept. 2010

How to cite this article: Volschenck, G.J., 2010,

‘Review article: The mountain motif in the plot of Matthew', HTS Teologiese Studies/ Theological Studies 66(1), Art. \#326, 9 pages. DOI: 10.4102/hts.v66i1.326

\section{This article is available} at: http://www.hts.org.za

\section{Note:}

Dr G.J. Volschenk is participating as a research associate of Prof. Dr Johan Buitendag, who is the Dean of the Faculty of Theology at the University of Pretoria, South Africa.

C 2010. The Authors. Licensee: OpenJournals Publishing. This work is licensed under the Creative Commons Attribution License.

\section{ABSTRACT}

This article reviewed T.L. Donaldson's book, Jesus on the mountain: A study in Matthean theology, published in 1985 by JSOT Press, Sheffield, and focused on the mountain motif in the structure and plot of the Gospel of Matthew, in addition to the work of Donaldson on the mountain motif as a literary motif and as theological symbol. The mountain is a primary theological setting for Jesus' ministry and thus is an important setting, serving as one of the literary devices by which Matthew structured and progressed his narrative. The Zion theological and eschatological significance and Second Temple Judaism serve as the historical and theological background for the mountain motif. The last mountain setting (Mt 28:16-20) is the culmination of the three theological themes in the plot of Matthew, namely Christology, ecclesiology and salvation history.

\section{INTRODUCTION}

The purpose of this article is to focus the attention of researchers, theologians and pastors once more on the importance of the mountain motif in the Gospel of Matthew's theology, structure and plot. Donaldson's (1985) research is a thorough and groundbreaking work in this regard, deserving the attention and focus that it received in my dissertation (Volschenk 2001) and in this review article. Donaldson focused our attention on the importance of the mountain motif in Matthew as a literary motif, as well as a theological symbol. Mountains appear frequently in Matthew as sites for events in the life and ministry of Jesus. This is a deliberate and intentional feature of the Matthean redaction. There are six important mountain passages in Matthew (Mt 4:8; 5:1//8:1;15:29;17:1-9;24:3; 28:16), where a mountain serves as the setting for a significant event in the ministry of Jesus. The mountain is thus an important setting and serves as one of the devices by which Matthew structured and progressed his narrative. Donaldson (1985:4) concludes that the three Matthean mountain scenes (Mt 4:23-5:1; 15:29-39; 28:16-20) present a generally positive picture of the person of Jesus and of his ministry with the disciples and crowds. Opposition and unbelief are generally foreign to Matthew's presentation of Jesus on the mountain. It is at this point where scholars have moved beyond Donaldson in their investigation of the interrelationship and connectedness of mountain and other theological themes such as faith. Narratological research has, in the past, emphasised the unity of the Gospel as a whole, as well as the importance of the plot of the narrative.

My aim in this paper is to climb the Matthean mountain and discover the geographical, structural and theological significance of this explorative journey or expedition.

\section{A REDACTION-CRITICAL METHODOLOGY IN PRACTICE}

\section{Preliminary remarks}

Donaldson's research is a groundbreaking endeavour. He refers to some of the results of earlier scholars that are either preliminary, off the mark or superficial. Some of the lasting results are that there are recurring Christological and ecclesiological themes that appear in Matthew's mountain passages. Donaldson (1985:15) draws attention to the absence of opposition and to the emphasis on the relationship between Jesus and those who have gathered around him on the mountain as the creation of an eschatological community bound to a teacher. One of the primary results is that mountains function as places of Christological manifestation. Several scholars attempt to discover the literary role of the motif in the structure of the Gospel as a whole. They suggest that each of Matthew's mountain scenes is linked in one way or another to the final scene in the sequence.

There is consensus that Matthew 28:16-28:20 serves as a summary and climax of many of Matthew's key themes and there is a possibility that this passage has the same functioning for the mountain motif. There is a gap in the research with regards to the possibility that the mountain in Matthew functions as a theological symbol. Volschenk (2001), however, showed that the mountain, as part of the space in Matthew's narrative, has a definite theological significance. The primary result is that the mountain is the setting which Jesus characteristically chose for his ministry.

\section{Redaction-critical methodology}

Donaldson (1985:18-21) briefly described the redaction-critical method that he would use as a tool in his investigation of the mountain motif in Matthew's Gospel:

This discipline assumes that the evangelists were authors and theologians in their own right, who, living in the midst of concrete and (at least potentially) identifiable church situations, shaped the Gospel traditions as they received them in order to address particular issues and needs which were present in those church situations. In this approach the Gospels are seen not as shapeless collections of units of tradition, but as carefully-crafted theological statements; the evangelists, by the same token, are not merely tridents but competent exegetes; the community not only transmits the Gospel tradition, but provides the setting in which and for which the tradition is shaped and interpreted.

(Donaldson 1985:18) 
Donaldson has a clear understanding of the assumptions of the redaction-critical or historical-critical method and the shortcomings thereof. According to Donaldson (1985:18), the redaction-critical task is twofold:

- The task is, on the one hand, aimed at horizontal analysis, to uncover and examine the various theological and practical motives which governed the evangelist in his work. The Gospel is compared with its sources in order to discover significant patterns in the way in which the evangelist has altered, deleted, rearranged or recast the material as he received it.

- On the other hand, vertical analysis looks at the overall composition of the Gospel to discover its themes and the structures on which it is built. The results of the current study are used to illuminate the setting in which this work was done.

Donaldson's redaction-critical study gives us a comprehensive picture of the background of the mountain motif in Second Temple Judaism, and of the mountain as a theological symbol. The main criticism of his work is on the second level, having to do with vertical analysis. Donaldson did not explore the overall composition or structure of Matthew as a narrative in more depth, which would have allowed him to investigate the interrelationship between the mountain and related themes within the plot of the Gospel of Matthew (see the section headed 'The plot of the Matthean narrative' below).

\section{Assumptions about the background investigation}

Donaldson (1985:13) focuses his research on the significance of Matthew's mountain theme against the background of Second Temple Judaism. His primary attention is, thus, the religious tradition that had influenced early Christianity in general and Matthew in particular. His second assumption is that the church for which Matthew was written was JewishChristian in orientation, and therefore dependant for its world of ideas largely on the traditions of Second Temple Judaism. The difficulty is caused by the two tendencies in the Gospel that coexist in tension to some extent. Such tension is that of JewishChristian particularism, on the one hand, and the universalistic interest in Gentile mission, on the other. Donaldson (1985) is well aware of the difficulties of, and criticisms levelled against, the above assumption:

[I]t is argued that the Gospel was written for a Greek-speaking but largely Jewish-Christian church which was in the process of consolidating its own life and self-understanding in a context in which, as a result of increasing Pharisaic opposition, it was being pushed in a greater or lesser degree to the margins of Jewish life. This church was open to the Gentile mission, but valued its Jewish heritage and wanted to give a greater place in Christian practice to a re-interpreted Torah, in order to counter the antinomianism which it feared was endemic in that mission. If Matthew wrote in and for such a church, then it can be safely assumed that both he and his readers were thoroughly conversant not only with the OT but also with the developed exegetical traditions of Second-Temple Judaism

(Donaldson 1985:14)

Donaldson (1985) states his position on the Sitz im Leben of Matthew's Gospel as follows:

Matthew's Gospel was written in the period after the war but before the Birkhat ha-Minim declaration was fully in force, for a Hellenistic Jewish-Christian community which, while open to a properly-conceived Gentile mission even if it held on to its Jewish heritage, was being forced to re-examine its own identity as the Pharisees of Jamnia carried out their reconstruction of a more narrowly defined Judaism.

(Donaldson 1985:16)

It is necessary to emphasise the critique against the redactionalcritical methodology in establishing the Matthean community. The question is whether it is in any way possible to reconstruct the Matthean community. Stanton (1992; see also Volschenk
2001:99) criticised the history of the reconstruction of the Matthean community as follows:

The paragraphs which follow will confirm that redaction critics have often drawn over-hasty conclusions about the circumstances and the development of Matthean communities. Any attempt to reconstruct their history must inevitably look beyond the meagre evidence of Matthew itself and draw heavily on other considerations concerning the origins of earliest Christianity.

(Stanton 1992:47)

Kingsbury (1991) also criticises the methodology of the redactioncritical approach:

To move from text to social situation by simply invoking the principle of transparency is, owing to the high degree of subjectivity involved and the paucity of independent evidence for corroborating one's findings, hazardous indeed. On this score, witness the shipwreck so many redaction-critical hypotheses regarding the community of Matthew have suffered. Similarly, to move from text to social situation by means of a model or typology brought to the text from the outside runs the risk of forcing the text into a procrustean bed. In what direction, then, lies progress in coming to grips with this problem of moving from text to social situation? Generally speaking, one must wonder whether biblical social historians, in trying to solve this problem, might not do well to throw in their lot with biblical literary critics.

(Kingsbury 1991:262)

\section{Beyond the redaction-critical exegesis}

Literary critics or narratology moved a step forward in the exegesis process. After first trying to identify the genre of the Matthean Gospel, they studied the literary structure of the Gospel text as a whole. They then distinguished between the surface structure and the deep structure of the text. Such an approach is also called the text-immanent or holistic approach to text interpretation. Van Aarde (1994; see also Volschenk 2001:102) describes the distinction as follows:

Under the surface lie the interrelationships and interweaving of linguistic structures which, semantically, denote the true meaning of the text. This is the level known as the 'depth structure'. French Structuralism makes a distinction between the levels on which the depth structure is situated. Apart from the fact that below the current narrative there is a linguistic depth structure ... below this linguistic depth structure there is also a 'narrative surface structure' and a 'narrative depth structure'. The plot of the narrative is generated in the 'narrative depth structure', embodied in the 'narrative surface structure' and finally manifested in the 'linguistic surface structure' in current linguistic forms - such as words, combinations of words, sentences, combinations of sentences, pericopes and so forth. These linguistic signs serve as the language symbols of the various 'actants' encountered on the level of manifestation. An 'actant' is generally a character in the narrative, but it can also be an interest group, an object, an institution, a predicate, and so on.

(Van Aarde 1994:27-28)

Van Aarde (1994:30) concluded that the genre of the Gospels is a narrative, which is the interaction between the plot and characters within a specific period of time and space. The plot is the logical sequence of the events and actions in the episodes from the beginning, through the middle, and to the end, or conclusion. In the section headed 'The plot of the Matthean narrative', I will briefly describe the plot of the Matthean narrative, as well as the interaction between certain aspects of the plot of the narrative.

\section{THE MOUNTAIN MOTIF IN THE SURROUNDING CULTURAL CONTEXT}

The objective of this review is to provide an overview of Donaldson's (1985) perspective of the place and function of the mountain motif in the structure of Matthew. Details of the results of the redaction-critical research will only be provided 
where doing so is deemed necessary. Donaldson's (1985) work is uniquely structured, in that it starts with the sacred mountain motif as it was used in those cultures, such as the Canaanite culture, surrounding Israel, thereby emphasising the wider context of the mountain motif. Donaldson then focuses in on the nub of the issue, namely that of Old Testament mountain theology, generally in terms of the Old Testament, and specifically in terms of Second Temple Judaism. He then discusses the mountain motif in the Gospel of Matthew, placing his redaction at the centre of his research.

\section{Sacred mountain motif in a wider context}

Sacred mountains and mountain symbolism were common features in the landscape of Israel's religious life from the earliest times up to the end of the Second Temple period and beyond. The redaction-critical study of the sacred mountains focuses our attention on Israel's mountain theology and provides a context within which the Jewish phenomena can be examined.

Sinai and Zion are the most significant mountain sites and symbols in the Old Testament. The Old Testament mentions a few mountains, though such mountains have little religious significance.

\section{Sinai/Horeb: The mountain of the Law}

Sinai is the prominent mountain setting for the giving of the Law (Pentateuch). The Sinai theology is relatively scarce outside the Pentateuch. The Sinai event is the basic presupposition for the rest of the Old Testament, for it was at Sinai that Yahweh bound Israel to himself as his people. Sinai is unquestionably foundational to Israel's theological self-understanding and, as such, has a twofold theological significance:

- Firstly, the encounter between God and his people on the mountain takes place in the form of a theophany, which is described in terms of storm, cloud and fire imagery. Yahweh freely comes to the mountain, with it becoming sacred due to his presence.

- Secondly, the theophany is part of a large covenantmaking ceremony. Yahweh's relationship with his people is covenantal in nature and, therefore, endowed with theological significance. Sinai is the mountain associated with Israel's constitution as a people.

\section{Mount Zion}

Donaldson indicates the significance of Mount Zion, which is the site of the Temple at the heart of Jerusalem. The mountain is also at the centre of some of the lofty theological conceptions and elevated religious language in the Old Testament. Mount Zion found its Sitz im Leben as a sacred mountain in the political and cultic circles of Jerusalem, as well as in the prophetic movements which grew up around them. The importance of Zion theology in the Old Testament can be summarised as follows:

- In terms of the concept of election, Mount Zion has been chosen by Yahweh as the place of his abode.

- The election of Zion is related to the wider covenantal concept of the possession of the land.

- Zion (or Jerusalem) is also had a dual political-religious role in Israel, especially in terms of the enthronement of the Davidic king. The inviolable Zion is, therefore, the centre of Yahweh's worldwide rule.

- Zion, as the holy mountain, is the central core of God's presence with his people, to which the latter responded with praise and worship. Such an understanding lies at the heart of Zion theology.

Donaldson (1985) concludes his discussion of the importance of Mount Zion to God's people as follows:

Mount Sinai was almost forgotten as Mount Zion gathered to itself many of the threads of Israel's religious tradition. Here on his holy mountain Yahweh is present with his people; here his king rules; here stands his sanctuary. If Sinai was the mountain of Israel's constitution, Zion, the holy mountain of God, became the living center of Israel's political and religious existence - the site and sign of God's continuing presence with his people.

(Donaldson 1985:41)

As a form of physical localisation of the relationship between Yahweh and his people, the sacred mountains of the Old Testament can most accurately be described as mountains of the Covenant. They are absolutely central to the theological selfunderstanding of Israel.

\section{The sacred mountain in Second Temple Judaism}

In Chapter 5 of his work, Donaldson gives an overview of the religious and political reality of Israel or Judaism during the period $200 \mathrm{BCE}-100 \mathrm{CE}$. The period was one in which external forces threatened to annihilate Judaism and internal tensions seemed ready to bring about its disintegration. However, Zion was the ideal, along with the Torah, which together provided the ideology that enabled Judaism to survive the onslaught of its enemies. The mountain symbolism and theology of Second Temple Judaism probably set the context or milieu in which the Gospel of Matthew was written (Donaldson 1985:81). The following conclusions can be drawn with regard to Second Temple Judaism:

\section{Mountain as the symbol and site of theological significance}

According to Donaldson (1985), there was common and widespread interest in the mountain as a symbol or site of religious and theological significance. Therefore, it is unlikely that the readers of Matthew would have taken the highly stylised and structurally prominent mountain settings of the First Gospel as merely casual geographical references. Mount Zion played a prominent role in catalysing significant developments in Zion theology, such as those of Zion as a cosmic centre and as the focal point of Heilsgeschichte (salvation history). Zion also played a significant role in the eschatological and apocalyptic literature in which cosmic and eschatological elements became fused in a new way. The Zionist tradition was more prominent in the literary and religious imagination of the period, than was Sinai, due to the continued existence of the Jerusalem temple.

\section{Four main types of religiously significant mountains}

The four main types of religiously significant mountains are the following:

Covenant mountains: 'The sacred mountains of the OT are best viewed as covenant mountains, i.e. sacred sites at which the covenant relationship between Yahweh and his people was established and maintained' (Donaldson 1985). The mountain played a significant role in every key event in the Heilsgeschichte.

Cosmic mountains: With the Hellenistic influence that was present in Palestine providing a bridge for the inflow of foreign ideas, an influx of cosmic concepts about Mount Zion, as well as about mountains in general, occurred into Jewish thinking. In terms of such thinking, mountains became the point of entry into the heavenly sphere. Jewish apocalypticism fused cosmic elements with eschatological ones.

Mountains of revelation (Jewish apocalypticism): Mountains of revelation were generally of two kinds:

- With the one kind, the revelation is in the form of divinelygiven information, which often concerns those events leading up to the End.

- With the other kind, which is more characteristically cosmic, the mountain provides a point of entry into the heavenly sphere, where the secrets of both Heaven and Earth are revealed. 
Eschatological mountains: During the period under discussion, the focus was both on Mount Zion as an eschatological site, as well as on other mountains in general. Mountains were treated as sites which carried with them both the potential and the promise of eschatological activity. The eschatological mountain is, according to Donaldson (1985:83), 'a special form of covenant mountain: it is the mountain where covenant promises are consummated'. In conclusion, the First Gospel was written at a time when an interest in mountains as eschatological and Messianic sites had reached its high water mark.

\section{MOUNTAINS IN THE STRUCTURE OF MATTHEW}

Donaldson's main contribution in Matthean research is his focus on the significance of the mountain motif in the First Gospel (see Chapters 6-13 of Donaldson's work). I shall briefly review the main results of his research, concluding with a critique of his methodology and results. I shall also suggest issues for future research. Donaldson (1985) discusses six prominent mountain passages in Matthew, namely those dealing with the following types of mountains:

- the mountain of temptation (Mt 4:8)

- the mountain of teaching (Mt 4:23-8:1)

- the mountain of feeding (Mt 15:21-39)

- the mountain of transfiguration (Mt 17:1-9)

- the Mount of Olives and the Olivet discourse (Mt 21:1;24-25)

- the mountain of commissioning (Mt 28:16-20).

\section{The mountain of temptation}

Donaldson (1985:93) concludes that Psalms 2:6-2:8 provides the background for the holy mountain of God (Ps 2:6) or the mountain of temptation. The holy mountain is the place of the enthronement of the Son - and therefore, in terms of the Messianic interpretation of Psalm 2, as against a background of eschatological Zion, the place where the world throne would be established. The primary significance of the three settings those of wilderness, temple and mountain - was that each of the settings was a place where eschatological events were expected to occur. As Donaldson (1985) asserts:

The point of the passage is rather that it is only by the humble obedience of the Son to the Father that fulfillment will take place. Because the desert, temple and mountain were the three main places at which eschatological fulfillment was expected, they were entirely appropriate settings for the testing of the Son and his vocation.

(Donaldson 1985:96)

Donaldson (1985:97) also highlights that the sequence of the settings - firstly the wilderness, secondly the temple, lastly the mountain - ties in with the sequence of expected eschatological events, according to Ezekiel (Mt 11:23; 10:4, 18; 43:2).

Despite the similarities with the Moses typology, such an aspect is secondary to the primary significance of the mountain motif, which is that of the larger pattern of Son-Christology. The dominant theme of the temptation narrative is the Sonship of Jesus, as a form of humble obedience to the Father (Donaldson 1985:99). The climax of the entire introduction to Matthew's Gospel (Mt 1:1-4:16) occurs when the baptismal voice from heaven proclaims Jesus' Messianic calling as God's Son. According to Donaldson (1985),

Matthew's point is clear: in the Temptation Jesus began to move along a path of humble obedience to the Father which, if continued, would lead inexorably to the Cross. Yet this is only half of what Matthew wants to say about Jesus as Son of God. For Matthew, the path of Sonship does not end with crucifixion but goes on to vindication. The glory rejected by the obedient Son at the beginning of the Gospel is fully bestowed at the end.

(Donaldson 1985:100)

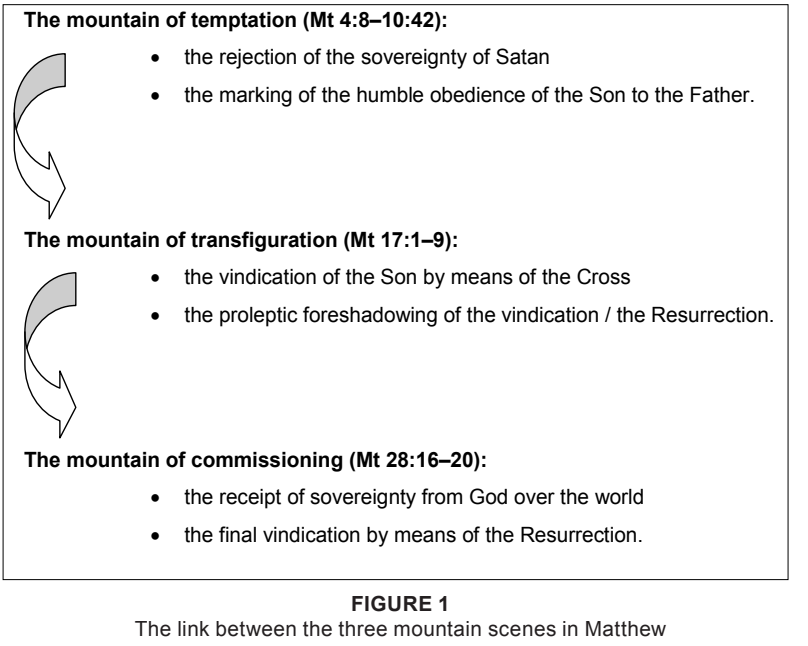

Donaldson (1985:100-104) asserts the link between the three mountain scenes in Matthew: the mountain of temptation (Mt $4: 8$ ), the mountain of transfiguration (Mt 17:5) and the mountain of commissioning (Mt 28:16-20). The proleptic vindication or foreshadowing that occurs between the three mountain scenes is described as follows:

The Baptism and Temptation serve to introduce the concept that Sonship must be characterized by humble obedience leading to the Cross. And this Matthean theme is taken up into another: that the path of obedient Sonship receives divine vindication, proleptically on the Mountain of Transfiguration and finally on the Mountain of Commissioning. As part of the Temptation Narrative, the mountain setting helps to define the path of true Sonship; as a link with the later mountains of Transfiguration and Commissioning, it foreshadows the vindication of the Son.

(Donaldson 1985:104)

Such an interrelationship can be described as can be seen in Figure 1.

\section{The mountain of teaching}

Though the second mountain scene overtly begins at Matthew 5:1 and ends at Matthew 8:1, there is general consensus that the Sermon on the Mount should be studied within the broader literary framework, or narrative context, in which it is placed (Mt 4:23-9:35). Once more, in this regard, Donaldson (1985:111115) denies any Moses typology, despite the numerous Deuteronomistic similarities.

The Sermon on the Mount is part of an event of eschatological fulfilment. The passage in question (Mt 4:23-25) describes the dawning of the eschatological light in Galilee. Jesus' ministry in Galilee culminates in the delivery of his discourse from a mountaintop, which is an event of eschatological fulfilment. His ministry to the assembled crowds is described in terms that are related to teaching, preaching and healing. Matthew considered Jesus' ministry as a sign of his Messianic vocation (Mt 11:2-6) and of his breaking in of the kingdom (Donaldson 1985:114; Mt 11:11-14). The crowds played an important role as a separate group within the eschatological community. According to Donaldson (1985):

Matthew has placed the Sermon in the context of a great gathering of the people of Israel to Jesus, whose ministry among them is a sign that the age of fulfilment has dawned. Such presence of the crowds with Jesus on the mountain is one of the distinctive features of Matthew's mountain scenes.

(Donaldson 1985:114)

Jesus himself is the gathering point for the people of God. Matthew 4:23-5:1 shows a widespread conformity to the pattern of Zion eschatology. The connection between the mountain 


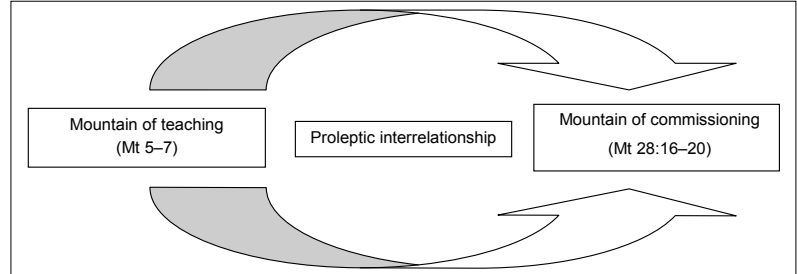

FIGURE 2

The link between the mountains of teaching and commissioning in Matthew

and the law that is found in Matthew's sermon suggests a Zion background (Donaldson 1985:117). The allusion to the city on the mountain (Mt 5:13-16), which is described as a city that cannot be hidden, is a clear indication of Zion eschatology. The allusion in question refers to the new Jerusalem, which is established on the highest of all mountains, so that it may form an appropriate centre for the restored people of God. The eschatological Jerusalem is the pivotal light for the entire world.

Donaldson (1985:120-121) ends his chapter on the mountain of teaching with a reference to the dialectical relationship between Jewish particularism and Gentile universalism. Such a dialectical relationship forms a link between the mountain of teaching $(\mathrm{Mt}$ 5-7) and the mountain of commissioning (Mt 28:16-20) (see Figure 2).

\section{Donaldson (1985) writes:}

There is thus a 'Bogen', or over-arching connection, between these two mountain scenes as well. The mountain on which Jesus teaches points ahead to the mountain on which he commands his disciples to propagate his teaching. The one looms over the other, with the result that the teaching of Mt 5-7 is funnelled through 28:16-20 to become the standard of Christian existence for the ongoing community - both Jewish and Gentile - of Matthew's own day.

(Donaldson 1985:120-121, emphasis added)

\section{Mountain of feeding}

Jesus gathers people to himself in eschatological fellowship, with the mountain serving as the site of an event of eschatological fulfilment. One indication of the mountain serving as such a site is the graphic depiction of Jesus' healing ministry, which is understood by Matthew as a sign of his Messianic identity and of the age of fulfilment.

The miraculous provision of food must also be seen as an eschatological event. During the Second Temple period, there was widespread expectation that the Messiah would invite the faithful to participate in a Messianic banquet. Accordingly, Jesus invited the Jewish crowds to share a meal with him, so that his ministry of healing and feeding could serve as a sign that the age of fulfilment had dawned. Donaldson (1985:128) concludes that, just as a mountain is a place of gathering, healing and feeding, it also functions as an eschatological site. Matthew took a mountain, or other geographical site, and used it as a setting that symbolised the eschatological ministry of Jesus, thereby imbuing it with theological significance.

Donaldson (1985:129) indicates that Matthew linked the mountain motif clearly with patterns of Zion eschatology. The researcher gave the following three reasons for making such an observation:

- Healing, which is portrayed in Isaiah 35:5, forms part of the final pilgrimage of Israel to Mount Zion.

- The feeding of the crowd on the mountain is related to the banquet that was to be the culmination of the gathering on Mount Zion (Is 25:6-10a).

- The gathering of the scattered sheep is also an indication of Zion eschatology (Es 34:14; Jr 31:10-12). The scattered flock will be gathered to the mountain of God, where it will be fed in abundance.

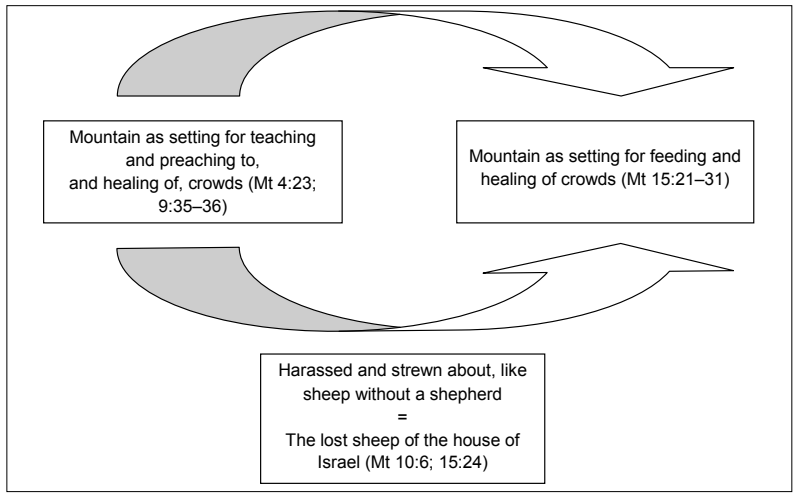

FIGURE 3

The link between the mountain setting (Mt 4:23; 9:35-36) and the summary statement (Mt 15:21-31) in Matthew

According to Donaldson (1985:129-130), this last point is very important because it links the previous mountain setting (Mt $4: 23$; 9:35-36) with the summary statement relating to the mountain setting (Mt 15:21-31). Such a linkage can be seen in Figure 3.

Donaldson (1985) describes the similarities between the abovementioned two passages and Matthew's combination of all the elements to form a pattern of Zion eschatology as follows:

So the crowds who gather to Jesus on the mountain are the lost sheep of Israel, harassed and helpless like a leaderless flock, and Jesus, who is depicted by Matthew as the promised Davidic shepherd of Israel (2:6), heals their afflictions and provides them with food in abundance. And this being so, Matthew's careful creation of a mountain setting here is clearly understandable in Zion terms ... But when all these features are taken together, the cumulative evidence is impressive. All the elements in this passage - the gathering of the crowds; the healing of the lame, maimed, blind and dumb; the allusion to Is 35:5f.; the feast of plenty; echoes of the pastoral metaphor; eschatological activity of the "God of Israel' and, above all, the mountain setting - are part of the Zion complex of ideas.

(Donaldson 1985:130)

The careful construction of Matthew 15:21-15:31 serves to highlight its theological significance within the structure of the Gospel. The event is not only eschatological in nature, but Donaldson (1985:131) also describes Matthew seeing it as the 'christological fulfillment of the expectations of Zion eschatology'.

Donaldson (1985:132-135) explains how Matthew tries to resolve the tension between Jewish particularism and Gentile universalism. Such resolution takes the form of the proleptic foreshadowing of the relationship between the two mountain scenes (see Figure 4).

The scene on the mountain (Mt 15:29-31) anticipates another mountain scene (Mt 28:16-20) at the end of the Gospel. In the latter scene the resurrected Lord stands on the mountain in Galilee at the focal point of a mission that is intended to gather all nations into the community of disciples. There is, therefore,

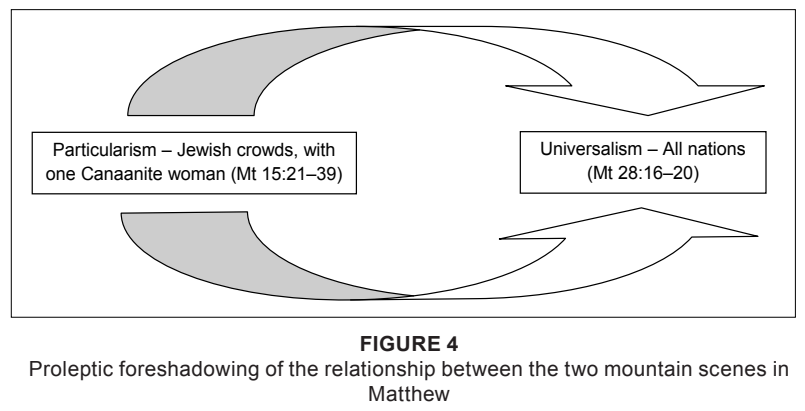


an implicit 'connection' between the two mountain scenes, which Donaldson (1985) discusses in the following terms:

This passage standing at the end of Jesus' ministry with the crowds in Galilee points ahead to another passage, standing at the end of Jesus' ministry on the Cross in Jerusalem, in which the tension is resolved. The mountain fellowship from which the Gentiles are excluded in 15:29-39 is offered to them in 28:16-20. The banquet on the mountain is a sign to the Gentiles that the time of their inclusion is near.

(Donaldson 1985:135)

\section{The mountain of transfiguration}

The significance of the mountain scene pertaining to transfiguration is apparent in the interpretation thereof, in terms of the structure of the narrative. The emphasis of such a scene is determined by our interest in mountains. We will, therefore, focus on the place and function of the scene in the narrative as a whole. No single interpretive background exists for the transfiguration narrative, due to the multiplicity of its features. Due to the variety and polyvalence of the symbolic elements in the account, several prototypes within Jewish thought are evoked, as can be seen in Donaldson's (1985) conclusion:

So we conclude that though there is apocalyptic colouring in the whole account, the basic shape of the narrative arises from the movement from Moses typology to Son-Christology. Because of its variety of associations, the mountain functions at three levels. Taking on characteristics of an apocalyptic mountain of revelation, it serves both as a reminder of Moses typology and as the place of the exaltation of the Son - the place where Mosaic categories are transcended.

(Donaldson 1985:148)

The mountain of transfiguration plays an important role in the outworking of Matthew's theological themes, particularly in his 'Son of God' Christology. Donaldson (1985:152) links the mountain of transfiguration retrospectively with the mountain of temptation and prospectively with the mountain of commissioning (see Figure 5), the transfiguration, as we argued, plays the role in Matthew of a proleptic vindication, confirming the rightness of the path chosen by Jesus in the temptation and providing a foretaste of the glory to be bestowed on the risen Lord.

There is a correspondence between the transfiguration narrative and the closing commissioning scene in Matthew. The enthronement of the Son and the vindication of the path of the Sonship, which are proleptically announced on the mountain of transfiguration, are fully declared on the mountain of commissioning. The correspondence between the two mountains can be stretched even further, as Donaldson (1985) makes clear:

On these three mountains Matthew has depicted for us in bold but economical fashion the whole pattern of the path of obedient Sonship and its outcome. On the Mountain of Temptation, which stands at the end of a section where Jesus' Sonship is declared and then tested (3.13-4.11), Jesus chooses obedience to the Father rather than the Lordship due to him as Son. On the Mountain of Transfiguration, after making clear to his disciples that the path of obedient Sonship must lead to the Cross, the disciples receive a foretaste of the vindicatory enthronement that will be his. And on the Mountain of Commissioning, the path of obedience having been followed to its end, Jesus appears as the fully enthroned Lord of heaven and earth.

(Donaldson 1985:155-156)

\section{The Mount of Olives (Mt 21:1)}

According to Matthew, there are three mountain settings in the final ministry of Jesus in Jerusalem: the Mount of Olives (Mt 21:1), the Olivet discourse (Mt 24:3) and the logion on the scattered flock (Mt 26:30-32). The difference between this mountain scene and the previous mountain settings is that the mountain in question has a particular geographical reference. The Mount of Olives is seen as Jesus' chosen place of retreat and

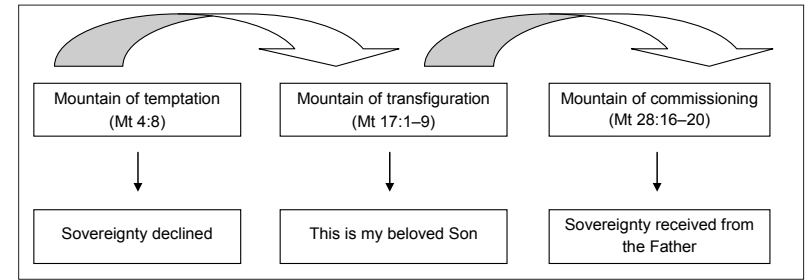

FIGURE 5

The link sequence of the mountain scenes in Matthew

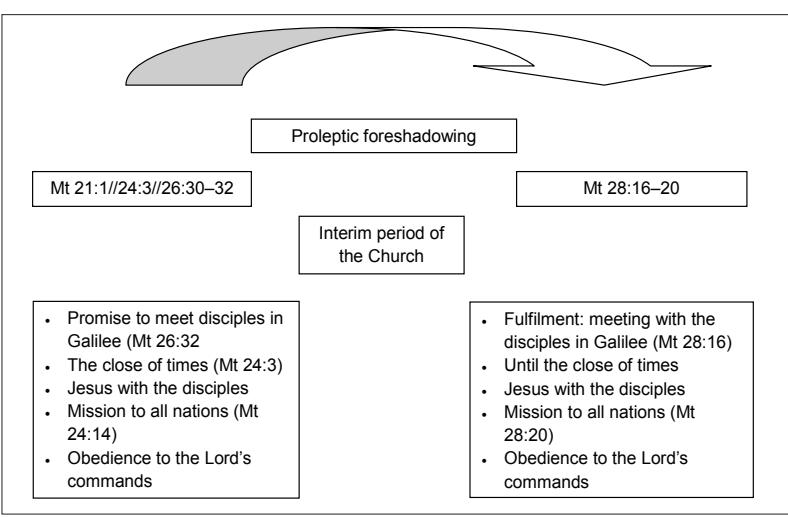

FIGURE 6

Similarities between the different mountain scenes in Matthew

the centre of his activities during his final days in Jerusalem. The passages of concern here describe the last days, focusing on the function of the Church during such times. The interim period is characterised by three phenomena (Mt 24-25), according to Donaldson (1985):

(1) [T] ribulation from without, as the Church faces suffering and persecution at the hands of the nation (24.9, 21-22); (2) apostasy and faithlessness within, as the Church is threatened by false prophets, lawlessness, and love grown cold (24.10-12, 23-26); and (3) the mission to the nations, which must be carried out before the End can come (24.14). This whole period lies under the shadow of an imminent 'parousia', which will bring a time not only of judgment for the nations $(24.30 ; 25.31-46)$, but also of judgmental separation within the Church (24.40-42, 48-51; 25.11-13, 26-30). Consequently, Matthew urges the Church to be watchful, so that when the Lord returns he will find them faithfully observing his commands (24.37-25.30).

(Donaldson 1985:165-166; emphasis added)

Donaldson (1985:161-169) focuses on the importance of the literary function of the Mount of Olives in the Gospel as a whole. Definite progress takes place in the story line or plot of the Matthean narrative between the account of the Mount of Olives and the Olivet discourse (Mt 21:1; 24:3; 26:30-32), and the account of the mountain of commissioning, which is given at the end of the Gospel (Mt 28:16-20).

The similarities between the different mountain scenes can be seen in Figure 6.

According to Donaldson (1985:167), the two passages mentioned above are more striking in their differences than in terms of their similarities (see Table 1).

TABLE 1

Correlation between Matthew 24-25 and Matthew 28:16-28:20

\begin{tabular}{ll}
\hline Matthew 24-25 & Matthew 28:16-28:20 \\
\hline $\begin{array}{l}\text { Sense of urgency and tension with regard } \\
\text { to the terrifying apocalyptic future. }\end{array}$ & $\begin{array}{l}\text { Concluding statement of the risen Lord } \\
\text { is characterised by a sense of calmness } \\
\text { and confidence. }\end{array}$ \\
$\begin{array}{ll}\text { Son of Man is seen as the absent master } \\
\text { Declaration of the Lord's presence with } \\
\text { (Mt 24:43-25:30). }\end{array}$ \\
\hline
\end{tabular}


The presence of the risen Lord with his church changed the whole outlook of the interim period. Many of the benefits, which, before the Resurrection, were associated only with the parousia, have in this interim period become proleptically operative for the Church. Donaldson (1985:167) describes the advance in the Matthean story line that culminates in Matthew 28:16 to 28:20 as follows:

[I]t represents a new understanding of the relationship of the Church to her Lord in the period leading up to the End. Mt 2425 , therefore, is not the evangelist's last word on this period. By linking these chapters with the closing scene of the Gospel, Matthew points the reader ahead to that passage in which the existence of the Church during 'all the days until the end of times' is most completely and finally described.

(Donaldson 1985:167)

According to Donaldson (1985:168), the allusions to the Mount of Olives and the Olivet discourse are primarily included in Matthew's narrative as comprising a mountain setting, and have a definite literary function within the structure of Matthew. The mountain is, therefore, a literary symbol in Matthew, with a definite theological significance.

\section{The mountain of commissioning}

The final mountain in the Matthean chain is the mountain on which the Resurrected One meets with his disciples and commands them to undertake a universal discipling mission. Matthew 28:16-28:20 is a summary and climax of the evangelist's theological interests in Christology, ecclesiology and salvation history. Matthew concludes his narrative with a description of the purpose of the mountain in terms of commissioning. The mountain plays an important literary role, as well as a variety of typological and theological roles, especially in Matthew $28: 16$. As literary symbol, the reference to the mountain of commissioning binds each of the other mountain scenes (and the themes developed in them) to one another. Matthew 28:1628:20 can, therefore, be seen as a consummation of all the themes (Donaldson 1985:175)

Donaldson (1985:179-188) presents a lengthy argument in support of the cohesiveness, the theological and typological background and the significance of Matthew 28:16-28:20. We can summarise his argument as follows:

- The mountain setting of Matthew 28:16 provides the clue to the connective thread running through the various elements of the passage and binding them tightly together.

- The passage, as a whole, forms an integral part of the profound unity provided by Matthew's Christological reinterpretation of Zion eschatology: the exalted Jesus is the gathering point for the eschatological people of God and the locus of God's presence with his people.

- The mountain setting functions as the vehicle by which such Zion expectations are transferred to Christ, in whom they find their fulfilment.

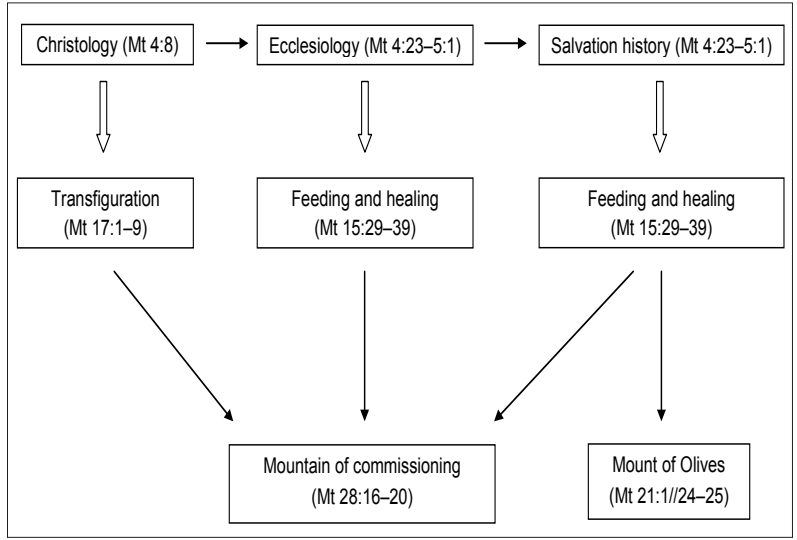

FIGURE 7

Thematic concurrency in Matthean mountain scenes
In conclusion, Matthew 28:16-8:20 is the culmination point of all the mountain scenes in the Gospel of Matthew. There are three major themes or strands that run throughout the Matthean mountain scenes and which culminate in Matthew's final passage, namely Christology, ecclesiology and salvation history. Such thematic concurrency can be seen in Figure 7.

Donaldson (1985) concisely describes the interrelationship of the mountain settings with the three theological strands as follows:

The 'christological theme' of the nature of true Sonship and the path of obedience that the Son must follow to receive sovereignty is set out principally in the Temptation and Transfiguration Narratives and brought to culmination in the closing scene though the authority of Jesus is also in view in the Sermon on the Mount (cf. Mt 7.28f.). The 'ecclesiological theme' of the gathering of the eschatological community and its constitution as the Church is developed in the Sermon, in the second feeding miracle, and ultimately in the final commissioning passage - though the community is also in view in the command to 'hear him' in Mt 17.5. These two themes together form the basis for Matthew's development of 'salvation history', in that the vindication of the Son ushers in an age of fulfillment in which the Church finds its existence. It is into this theme of salvation history that the Ecclesiological Discourse has been incorporated.

(Donaldson 1985:196)

\section{THE RELATIONSHIP OF THE MOUNTAIN AS LITERARY MOTIF AND AS THEOLOGICAL SYMBOL}

According to Donaldson (1985:196), the different mountain settings form a discernable pattern in Matthew, and the mountain serves as a literary motif, through which Matthew develops several of his distinctive theological themes. Just as the geographical settings in Matthew have a definite theological significance, the mountain settings form part of a literary pattern in the same Gospel. The diversity in the six passages that have been identified in the current article is discernable not only through the terminology with which the mountain in question is designated, but also in the nature and content of the particular scenes themselves. As Donaldson (1985) states:

This diversity, however, has been brought into a unity by means of the closing mountain scene. By means of a series of linguistic and structural details, Matthew has linked each of the first five mountain occurrences to the Mountain of Commissioning. Each mountain scene anticipates in some way or other the concluding scene, and each deals with themes that are brought to culmination there.

(Donaldson 1985:193-194)

The mountain also functions as a theological symbol in Matthew. According to Donaldson (1985:197), a theological symbol is a term with theological significance. The mountain is a literary device that aids Matthew's development of key theological themes. The mountain motif carries with it theological connotations from the religious and exegetical traditions of Second Temple Judaism. Matthew incorporated the theological ideas about the mountain into his narrative to form a cohesive and interrelated plot.

The primary significance of the mountain as a theological symbol lies in its emphasis on the Son-Christology theme. The mountain in Matthew is the place not only of the enthronement of the Son, but also of the establishment of the end-time community, as well as of the inauguration of the new age. The mountain of commissioning (Mt 28:16-20) is portrayed as the culmination of the consistent and undergirding Christological reinterpretation of Zion eschatology by Matthew. In terms of such a reinterpretation, the fulfilment of Old Testament hopes and of God's dealings with his people lies in Jesus, rather than in Zion. The mountain motif is a device used by the evangelist to make such a Christological statement. According to Donaldson (1985:199-200), 
[h] is the promised messianic Son whose enthronement to universal sovereignty had long been anticipated. He was the one to whom the people gathered for healing, feeding, teaching and eschatological fellowship.

(Donaldson 1985:199-200)

The conclusion that can be drawn in this respect is, therefore, that, in Matthew, the mountain has theological significance only because that is where Jesus is present.

\section{THE PLOT OF THE MATTHEAN NARRATIVE}

The plot of a narrative refers to the specific structure of time and space that is organised in a chronological cause and response sequence. Such a plot entails the interaction of the different characters with one another, as well as the development of the relationship between the different episodes that serves to move the plot to a climax. Van Aarde (1994) describes the interaction between the plot and characters in a narrative as follows:

The beginning of the plot introduces the action and creates expectations; in the middle the initial action is developed, and a denouement is anticipated, which is worked out in the conclusion. As the plot develops, and expectations are aroused in the reader, there is a suggestion of reader-association with the narrated characters - that is, sympathy or antipathy.

(Van Aarde 1994:106)

The plot, therefore, forms a well-structured, linear sequence from the beginning to the middle of the narrative, ending in the conclusion or climax.

It is my conviction that an intimate relationship exists between mountain and faith in the Matthean narrative, forming part of the development of the plot. Though the mountain, as a geographical entity, stands out in the landscape of the Matthean community and narrative, there is a deeper interrelationship between the mountain setting and such other theological themes as faith. Table 2 illustrates such an interrelationship.

Following on from the excerpts from the verses provided in Table 2, the following preliminary remarks can be made:

- The Sermon on the Mount (Mt 5-7) is presented as an important aspect of Jesus' ministry in the Gospel of Matthew. Jesus, who taught the theory of faith to his disciples on a mountain, did so without using either the word 'faith' or 'belief'.

- The theme of faith is closely interwoven with the healing acts that Jesus performed, as related in Matthew 8-9. By such intimate interweaving of faith and healing, Jesus demonstrated what faith is in practice.

- The glorification of Jesus (Mt 17) on the mountain is closely related to the mountain as a theological framework for faith (Mt 21). In Matthew 17:21 and 21:21, mountain and faith are specifically used together, thus emphasising the power of our faith.

We need a holistic, interdisciplinary approach toward unravelling the hermeneutical process of the text. The exegesis process of the text should move beyond the historical critical approach to a holistic, text immanent, narratological approach (Volschenk 2001:108). A paradigm shift in the interpretation of the Biblical text has indeed occured. Vorster (1988) describes the shift as follows:

The relation between theory and interpretation is now used positively to interpret the New Testament within a particular framework of understanding. On the ontological as well as the epistemological levels such an approach has far-reaching consequences. Because of the widening of the scope of the reality which can be studied, greater value should be put on the validity of statements, that is on their epistemological status. Perhaps this is one of the biggest shifts which are taking place in New Testament scholarship. Related to this aspect is the social dimension of New Testament science.

(Vorster 1988:42)
TABLE 2

The interrelationship between the mountain and other theological themes in Matthew

\begin{tabular}{|c|c|c|}
\hline $\begin{array}{l}\text { Chapter and } \\
\text { verse }\end{array}$ & $\begin{array}{l}\text { Expression of belief/ } \\
\text { faith/trust }\end{array}$ & Mountain reference \\
\hline Mt 4:8 & - & '...to a very high mountain...' \\
\hline Mt 5:1 & - & $\begin{array}{l}\text { '...he went up on the } \\
\text { mountain...' }\end{array}$ \\
\hline Mt 5:14 & - & '...city being on a mountain...' \\
\hline Mt 8:1 & - & $\begin{array}{l}\text { '...come down from the } \\
\text { mountain...' }\end{array}$ \\
\hline Mt 8:10 & '...found such faith in Israel.' & - \\
\hline Mt 8:13 & '...just as you believed.' & - \\
\hline Mt 9:2 & $\begin{array}{l}\text { '...Jesus having seen their } \\
\text { faith...' }\end{array}$ & - \\
\hline Mt 9:22 & '...your faith has healed you.' & - \\
\hline Mt 9:28 & 'Do you believe that...' & - \\
\hline Mt 9:29 & $\begin{array}{l}\text { 'According to your faith, let it } \\
\text { happen to you.' }\end{array}$ & - \\
\hline Mt $14: 23$ & - & $\begin{array}{l}\text { '...he went up onto the } \\
\text { mountain...' }\end{array}$ \\
\hline Mt $15: 28$ & $\begin{array}{l}\text { 'Jesus said unto her: "Your } \\
\text { faith..."' }\end{array}$ & - \\
\hline Mt 15:29 & - & '...gone up onto the mountain...' \\
\hline Mt 17:1 & - & $\begin{array}{l}\text { '...led them up onto a } \\
\text { mountain...' }\end{array}$ \\
\hline Mt 17:9 & - & $\begin{array}{l}\text { '...coming down from a } \\
\text { mountain...' }\end{array}$ \\
\hline Mt 17:20 & 'Because of your unbelief...' & - \\
\hline Mt 17:20 & '...if you have faith...' & $\begin{array}{l}\text { '...you will say to this } \\
\text { mountain...' }\end{array}$ \\
\hline Mt 18:6 & '...little ones believing in me...' & - \\
\hline Mt 21:21 & $\begin{array}{l}\text { '...if you have faith and doubt } \\
\text { not...' }\end{array}$ & $\begin{array}{l}\text { "....you will say to this } \\
\text { mountain..." }\end{array}$ \\
\hline Mt 21:22 & '...believing...' & _- \\
\hline Mt 21:25 & 'Why did ye not believe him?' & - \\
\hline Mt 21:32 & '...you did not believe him.' & - \\
\hline Mt 21:32 & $\begin{array}{l}\text { '....tax collectors and prostitutes } \\
\text { believed him...' }\end{array}$ & - \\
\hline Mt 23:23 & '...mercy and justice and trust...' & - \\
\hline Mt 24:10 & $\begin{array}{l}\text { '...shall many be offended [by } \\
\text { the faith]...' }\end{array}$ & - \\
\hline Mt 24:23 & '...believe it not...' & - \\
\hline Mt 24:26 & '...believe it not.' & - \\
\hline Mt 27:42 & '...we will believe in him.' & - \\
\hline Mt 28:16 & - & $\begin{array}{l}\text { '...into a mountain where Jesus } \\
\text { had appointed them.' }\end{array}$ \\
\hline
\end{tabular}

\section{CONCLUSION}

Donaldson's book focused the research community's attention on the mountain motif in Matthew's Gospel. The motif is a literary device which is used to emphasise theological significance and the Christological fulfilment, or the Old Testament hopes of the people of God in the imminent coming of Jesus Christ. The primary focus or theological centre of Matthew is the SonChristology, which reaches its culmination in the ultimate mountain, that of commissioning (Mt 28:16-20). Donaldson highlighted the six primary mountain scenes, in which the three theological themes of Christology, ecclesiology and salvation history also reached their culmination in the mountain of commissioning. The last mountain scene is, consequently, the culmination of all the mountain scenes in Matthew.

The main criticism that can be levelled against Donaldson is that he does not take his research a step further by engaging in a narratological study of Matthew. Consequently, he falls short of identifying the place and function of the mountain motif, with its related theological themes, such as faith, healing and teaching, in the plot and structure of the Matthean narrative as a whole. We have indicated the interrelatedness of the mountain motif in Matthew with the expression of faith or unbelief as a reaction to the presence of Jesus, the Son of God. Despite the 
above critique, Donaldson's research provides a comprehensive demonstration of the application of redaction-critical research to the New Testament and his work is recommended to all whom it might concern.

\section{REFERENCES}

Donaldson, T.L., 1985, Jesus on the mountain: A study in Matthean theology, JSOT Press, Sheffield.

Kingsbury, J.D., 1991, 'Conclusions' in D.L. Balch (ed.), Social history of the Matthean community: Cross-disciplinary approaches, pp. 259-269, Fortress Press, Minneapolis.

Stanton, G.N., 1992, A gospel for a new people: Studies in Matthew, $\mathrm{T} \& \mathrm{~T}$ Clark, Edinburgh.
Van Aarde, A.G., 1994, God-with-us: The dominant perspective in Matthew's story, HTS suppl. 5, Gutenberg, Pretoria.

Volschenk, G.J., 2001, 'Eksegeties-metodologiese vooronderstellings van die ondersoek na die ekonomie in die leefwerreld van Matteus: Toegepas op land, grondbesit en die jubilee [Exegetic-methodological presuppositions of the inquiry into the economy of the world of Matthew: Application to land, land ownership and the jubilee]', DD dissertation, Department of New Testament Studies, University of Pretoria.

Vorster, W.S., 1988, 'Towards a post-critical paradigm: Progress in New Testament scholarship', in J. Mouton, A.G. Van Aarde \& W.S. Vorster (eds.), Paradigms and progress in theology, pp. 31-48, HRSC Studies in Research Methodology No. 5, HRSC, Pretoria. 